\title{
Qadhat - a comparative study of ancient and new lime mortar from the Marib province/Yemen
}

\author{
Christian Weiss • Iris Gerlach
}

Received: 5 August 2008 / Accepted: 4 March 2009 /Published online: 24 March 2009

(C) Springer-Verlag 2009

\begin{abstract}
Qadhat is the name for a lime mortar in Southern Arabia. Its usage has a long tradition. This work describes physical and mineralogical properties of ancient, historical and new samples, which seem to have been produced the same way. XRD, thin sections and SEM analyses show the similarity of the material. It consists of aggregates of volcanic material that are rich in volcanic glass and lime as binder. The production process includes several hours of crushing the material, which produces fine-grained splinters of aggregates in the binder matrix and gives the mortar a high stability. A weathering test with sodium sulphate on different samples confirms that the stability of this mortar is the result of the production process.
\end{abstract}

Keywords Qadhat· Lime mortar· Mortar.

Volcanic material $\cdot$ Binder matrix

\section{Introduction}

The use of mortars has had a long tradition since ancient times and is described in many studies (e.g. Moropoulou et al. 2003; Lanas and Alvarez 2003). In Southern Arabia, a special lime mortar with the name Qadhat is a common

\footnotetext{
C. Weiss $(\square)$

Institute of Paleontology,

Loewenichstr 28,

91054 Erlangen, Germany

e-mail: weiss@pal.uni-erlangen.de

I. Gerlach

Deutsches Archäologisches Institut,

Sana'a Brunch c/o German Embassy Sana'a,

P.O. Box 2562, Sana'a, Yemen

e-mail: dai.sanaa@y.net.ye
}

building material which was continually in use from the first century B.C. to modern times (Brunner 1989; Klessing 1997). Also in the Sabaean Kingdom of Marib, this lime mortar was often used for different constructions mostly connected with the ancient irrigation buildings. The long tradition in using Qadhat and the availability of samples from several periods allows a unique insight into ancient mortar processing techniques and high technological knowledge about its production.

\section{Historical context}

Marib, the heart of the legendary kingdom of Saba, is situated in an arid area on the edge of the ar-Rub' al-Khali desert, $135 \mathrm{~km}$ east of the Yemeni capital Sana'a. With its nearly 100 ha, the Sabaean capital forms one of the largest ancient cities in Southern Arabia and counts as one of the culturally most significant historical sites of the Arabian Peninsula. Marib forms the largest oasis landscape that was artificially created in ancient times and was in continual operation for thousands of years - to various extents and with ever-changing technologies. Water occurred in the wadis of the Oasis of Marib only twice a year as a result of the monsoon rains in the Yemeni highlands. Irrigation systems specifically designed for this weather phenomenon were, therefore, imperative for the formation of larger sedentary social systems during the Bronze Age. At first, the techniques applied only allowed the supply of water to a small community. However, with the building of the Great Dam complex, it was possible from the seventh century B.C. onwards to irrigate an area of up to 9,600 ha. This meant that Marib was not only in a position to nourish the local population but also possessed the economic basis for guaranteeing supplies to the caravans. The outstanding significance of Marib within the ancient Southern Arabian 
kingdoms is derived from the optimal utilisation of the prevailing environmental conditions.

The Great Dam is Marib's most impressive monument. The northern and southern outlets are still preserved and are connected by a $680-\mathrm{m}$ long dam, consisting of heaped earth faced with stones (Brunner and Haffner 1986; Brunner 1998; Vogt 2003b). The sluices were built from the sixth or seventh century B.C. onwards to supply the oasis with water. The present shape dates to the sixth century A.D., and the structures reflect its age, its many alternations and repairs, and in addition, to raise its height. The Oasis of Marib was abandoned when a severe break in the dam, reported in the Kor'an, occurred during the seventh century.

On this dam and on numerous other irrigation systems (distributors, channels), from the sixth century A.D. onwards, Qadhat was used as plaster to make the walls waterproof. During this phase spoils from already derelict buildings in the whole Oasis were reused. As these stones could no longer be set exactly to fit on each other, the joints were caulked with Qadhat (Vogt 2004). In addition, quarry stone walls in the many water distribution constructions were plastered with a continuous layer of Qadhat.

Another important building in Marib is the Baran temple. It was built at the latest in the ninth century B.C. and was in use for 1,500 years. Since then, it was covered by desert sands. Originally, Qadhat could be found as wall plaster on natural stone walls and benches in the later period of this temple (Vogt 2003a). The originally surface with carved pictures of an ibexes are still preserved.

The city of Sirwah is situated $40 \mathrm{~km}$ west of Marib. During the first millennium B.C., besides the ancient metropolis of Marib, it formed the most important centre of the Sabaean kingdom; $14 \mathrm{C}$ datings provide evidence of a population of Sirwah and possibly even the existence of a ritual site during the Bronze Age (middle of second millennium B.C.). Already at the beginning of the first millennium B.C., an urban centre developed there. Within the city, which was only 3 ha in area and surrounded by a mighty fortification wall, huge monumental buildings were erected. The most dominant were the numerous sacred buildings that were distributed across the whole of the city area. The largest of these sanctuaries is the Almaqah temple, of which the main building phase dates back to the middle of the seventh century B.C. and was continually in use until the third century A.D. It is built completely out of stone masonry without ancient mortars. Only in later times, from the first century B.C. onwards, Qadhat was used for special cultic installations like tubs for washing ceremonies. Also, Qadhat was used during Islamic times when the temple was built over with houses. It was used as sealing material in plumbing units. The age of these buildings ranges between 150 and 200 years (Gerlach 2003; Fig. 1).

\section{The building material}

The Sabaean culture had a long tradition in stone masonry (Brunner 1989; Bessac 1998; Weiss et al. 2007). The usage of Qadhat became common in the late Sabaean Kingdom, while the stone processing was decreasing; it was not used as binder for stones but as a wall covering and as a sealant for irrigation systems and other installations which could be connected with the use of water. Qadhat first appeared approximately in the first century A.D. and is known on many ancient sites in South Arabia. In Marib it was used as plaster for the walls of the dam to seal them up (Vogt 2004). The top of the wall is only made of loose-packed stones covered by a thick Qadhat layer. Numerous irrigation systems in the Marib oasis, which are made of untreated

Fig. 1 Ancient places in Yemen. The cities in the study area, Sirwah and Marib, are marked with stars

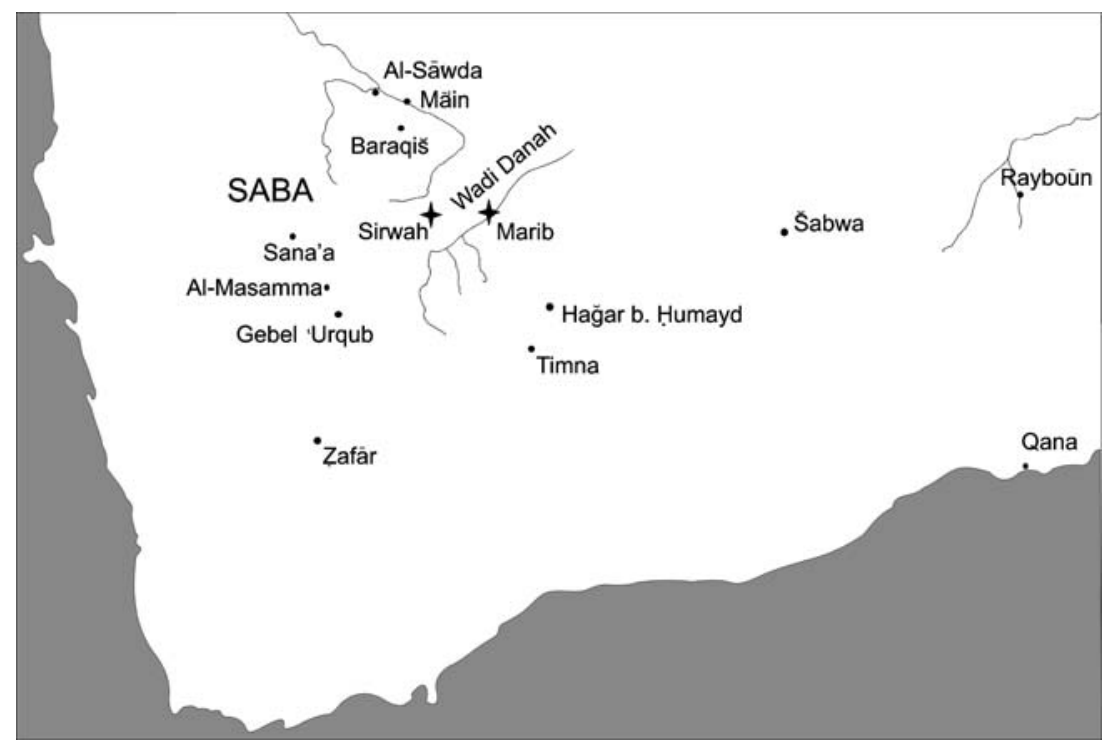


stones and covered by Qadhat, are built the same way (Vogt 2004). During Islamic times until today, it was used for ornamental work and as sealant. Furthermore, lime mortars ae important materials for the restoration of archaeological sites in Yemen. Here, it is used for topping and covering open parts of walls.

The mortar is a mixture of volcanic material and lime. The aggregates consist of coarse-grained volcanic materials, which are highly porous and which contain a high amount of amorph volcanic glass. The binder is slaked lime. Nowadays, a high pure carbonate, from the region of the Hadramaut Mountains in Eastern Yemen is used for the Qadhat production. The basic material is burned lime blocks with a size up to $15 \mathrm{~cm}$. The blocks are mixed with water and slaked for 2 days before processing them further. The materials were mixed and crushed by hand using stones until the mortar had reached a homogeneous, paste-like consistency. The stones have a size of approximately 10 to $15 \mathrm{~cm}$ with a flat lower side and the process takes several hours. Then the mortar is applied on the wall in several layers and later it is compacted by crushing it with stones. The final layer is mortar with finegrained aggregates, which form a watertight surface. The last step, 3 to 4 days later, is to evenly apply hot organic fat (sheep fat) as a hydrophobic layer over the mortar. This production is done by hand and is time consuming; the mortar however has a high elasticity and plasticity and it is highly resistant to weathering.

Chemical analyses of ancient mortar samples from Marib made by (Brunner 1989) and the Swiss cement industries offer the results of 38 wt.\% $\mathrm{SiO}_{2}, 12$ wt.\% Al, 9 wt.\% Fe,
21 wt.\% $\mathrm{Ca}$ and 2 wt.\%K. The binder of those samples consists of calcite with quartz, dolomite and little clay minerals.

The climate in the Marib region is arid to semi-arid. The annual rainfall ranges between 200 and $300 \mathrm{~mm}$. Most of the rain falls during the monsoon season. The temperature is rarely below $0^{\circ} \mathrm{C}$ and if so, only during dry seasons. Material for the mortar production can be found near historical places. The regional geology consists of volcanic rocks of Tertiary to Holocene ages (Kruck et al. 1996); they can comprise a high amount of volcanic glass. The ultra pure carbonates (less than 2 wt.\% insoluble residue) originate from Jurassic ages and belong to the Amran group. Both the volcano material and the lime stones from the mountains around the oasis are well available. The Jurassic stones were often used as building stones in Marib and Sirwah. Nowadays, the lime from the Hadramaut (Eastern Yemen) is used (Fig. 2).

\section{Methods}

Bulk samples of unweathered ancient mortars were taken from the dam in Marib in several places to get a wide range of different material. Samples from the Islamic time were taken from the excavation material on the Almaqah temple in Sirwah. New material was sampled during restoration work on the Almaqah temple. Local workers, who used traditional methods, produced the mortars. Moulds measuring $7 \times 7 \mathrm{~cm}$ were filled with material and dried over a 29-day
Fig. 2 Qadhat on the Sabaean irrigation systems in Marib. a Qadhat as a sealant for joints on a wall of natural building stones at the dam of Marib. b Irrigation dam at the Marib oasis made of stones, which are covered and stabilised with Qadhat. c Broken irrigation dam wall at the Marib Oasis. The figure shows the structure of the walls, which consist of large stones, stabilised with Qadhat on the outside. d Wall covering, consisting of a 20 -cm thick layer of Qadhat
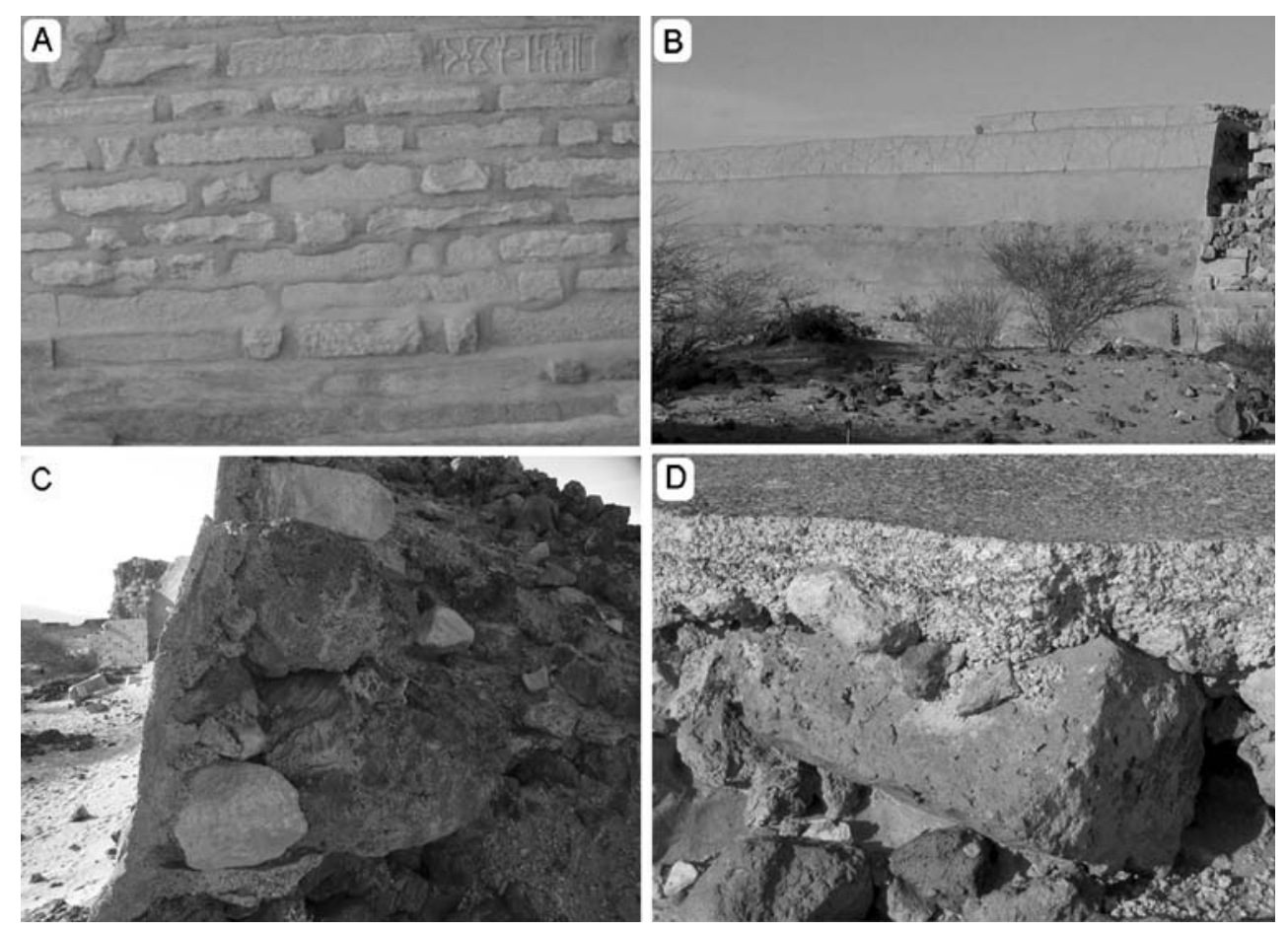
Table 1 Description of the samples with age, binder content $\left(\mathrm{CaCO}_{3}\right.$ in wt.\%), water uptake and thermal characteristics

\begin{tabular}{|c|c|c|c|c|c|c|}
\hline Sample & Description & Age & $\mathrm{CaCO}_{3}$ (wt.\%) & Water uptake (wt.\%) & LOI $\left(550^{\circ} \mathrm{C}\right)(\mathrm{wt} . \%)$ & LOI $\left(750^{\circ} \mathrm{C}\right)($ wt. $\%)$ \\
\hline nu1 & US material (Sirwah) & New & 34 & 43 & 0.26 & 6.46 \\
\hline nu2 & US material (Sirwah & New & 35 & 47 & 0.47 & 4.46 \\
\hline $\mathrm{n} 1$ & S material (Sirwah & New & 35 & 16 & 4.55 & 13.24 \\
\hline $\mathrm{n} 2$ & S material (Sirwah & New & 33 & 15 & 3.54 & 10.44 \\
\hline o1 & Dam (Marib) & Sabean & 29 & 14 & 3.23 & 14.04 \\
\hline o2 & Dam (Marib) & Sabean & 30 & 17 & 1.83 & 27.24 \\
\hline 03 & Dam (Marib) & Sabean & 45 & 16 & 2.24 & 23.20 \\
\hline o4 & Temple (Sirwah) & Islamic & 26 & 15 & 3.35 & 13.81 \\
\hline o5 & Dam (Marib) & Sabean & 55 & 16 & 2.56 & 8.49 \\
\hline 06 & Dam (Marib) & Sabean & 22 & 15 & 3.17 & 11.73 \\
\hline 07 & Temple (Sirwah) & Islamic & 26 & 16 & 5.19 & 18.38 \\
\hline o8 & Dam (Marib) & Sabean & 23 & 10 & 3.89 & 22.97 \\
\hline
\end{tabular}

US material relates to the samples (nu1 and nu2) taken before crushing the mortar, S material (n1 and n2) are samples of crushed material. The numbers o1 to o8 are historic samples taken on the old dam of Marib and from the Islamic settlements in Sirwah

period. Thin sections $5 \times 5 \mathrm{~cm}$ in size were made of every sample. Before, the material had been impregnated with bluecoloured epoxy resin in a vacuum chamber which made the pore space visible. Of the selected samples, scanned electron microscope (SEM) figures were made to show details of the mineral morphology and the crystal size. The carbonate content was analysed by weighing the sample and dissolving the calcium carbonate in hydrochloric acid, centrifuging them several times with distilled water to remove the chloride ions, drying the insoluble residue and weighing them again. The grain size was analysed by wet sieving. The carbonate was removed with hydrochloric acid and the samples were cleaned with a centrifuge to remove the chloride ions before wet sieving. Water uptake was measured by covering the samples with water for $12 \mathrm{~h}$ and weighing them in a dry and wet condition. The XRD measurements were made with a Bragg Bretano diffractometer (D 500, Siemens), equipped with a copper anode, a nickel $\mathrm{K} \beta$ filtre and a variable aperture $\left(<10^{\circ}\right)$. The measuring range of the $2 \theta$ corner was from $1^{\circ}$ to $60^{\circ}$. Thermal analyses were carried out in a heating chamber.
The samples were heated from $200^{\circ} \mathrm{C}$ to $600^{\circ} \mathrm{C}$ and at $750^{\circ} \mathrm{C}$ (Moropoulou et al. 2002, 2003), under static atmospheric conditions up to the end temperature by $10^{\circ} \mathrm{C} / \mathrm{min}$. Crystallisation of salts in building materials is an important method of quantifying their decay (Arnold and Zehnder 1989; Scherer et al. 2001). Commonly sodium sulphate is widely used in accelerated durability tests (Price 1975). One step of the test is the immersing of samples in a $10 \%$ sodium sulphate solution for $2 \mathrm{~h}$ and drying them in an oven at $105^{\circ} \mathrm{C}$ for $22 \mathrm{~h}$. The test cycles are repeated until a weight loss of more than $10 \mathrm{wt} . \%$ is reached. For the test, two samples of new mortar which was produced in the traditional way were chosen. One sample was taken during the production before the mortar was crushed.

\section{Results and discussion}

All samples appear to be very similar in texture; only the occurrence of cements in older samples and the grain
Fig. 3 Grain size distribution of volcanic material before processing and after several hours of hammering. Graph $A$ the aggregates before mixing with the lime, $B$ is after $2 \mathrm{~h}$ and $C$ after $3 \mathrm{~h}$ crushing the mortar

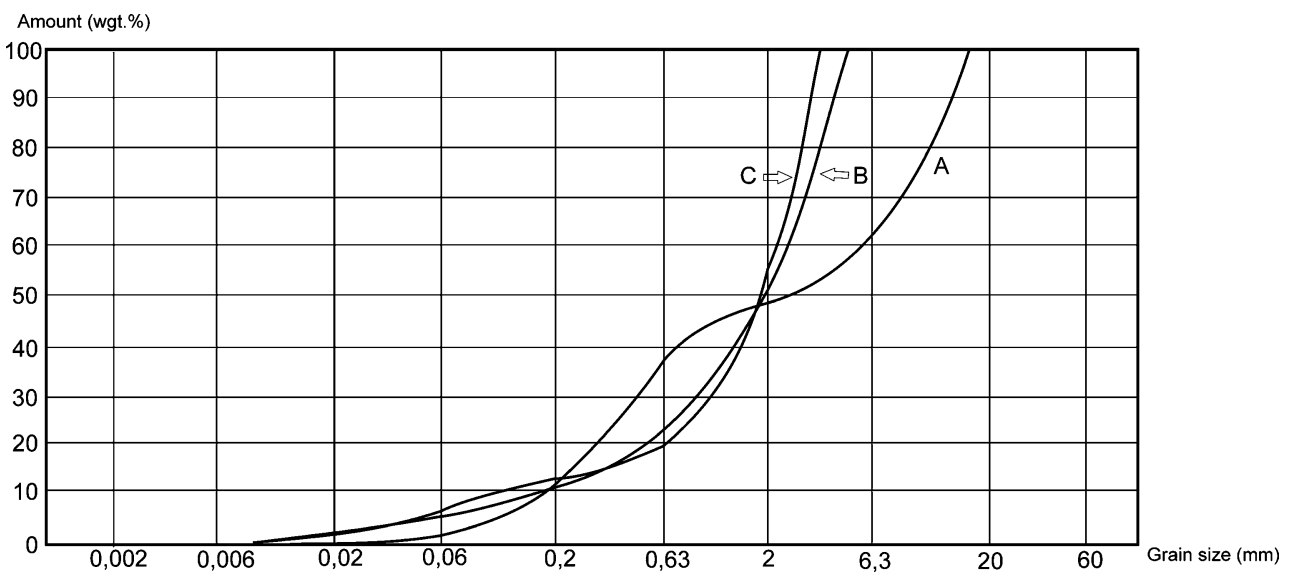


Fig. 4 Thin sections of ancient and new samples. a, b Overview of a sample of newly produced Qadhat. Both figures show fragile volcanic fragments in a dense matrix of binder material. In the binder are numerous small splinters of the aggregate material. c A thin section of historic material from Sirwah. Beside a large volcanic clast with feldspars, a large recrystallised lime clast can be seen in the left side. $\mathbf{d}$ A section of material from the dam of Marib. It shows small, very fragile volcanic glass in a dense matrix. The pore space of the glass is filled with carbonate
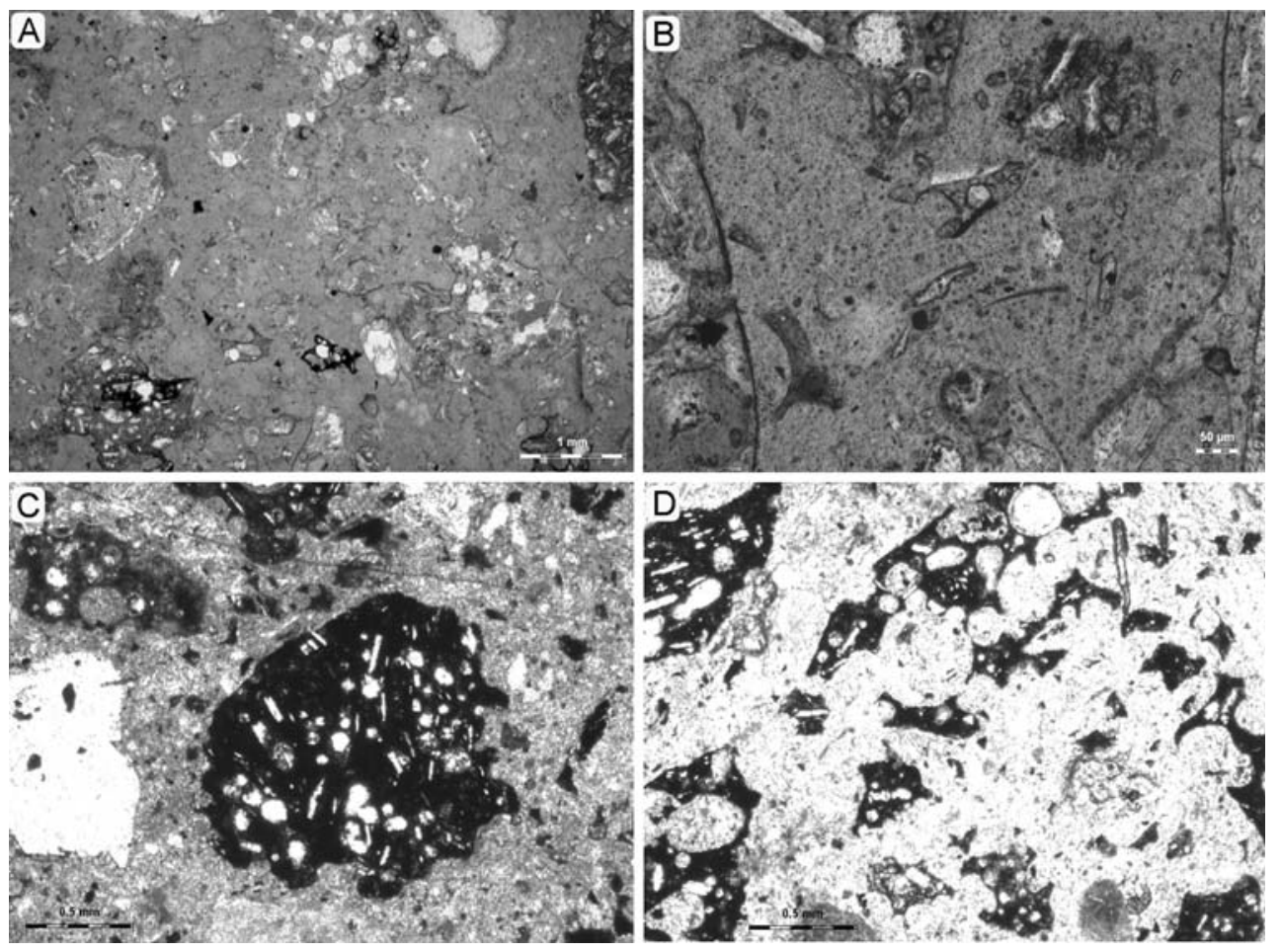

allows a differentiation. The characteristic texture of the samples is embedded volcanic material in a fine-grained matrix. In the samples of new mortar (nu1, nu2, n1 and n2), the high pore space of the aggregates is almost unfilled with the binder. Especially the intra-particle pore space of closed cavities contains no material. In the samples of ancient material, these pores are filled with fine-grained sparitic cements, which are the result of a long exposure to weather. This allows a second carbonatisation in pore space, which has no direct connexion to the binder, and the moisture can penetrate the pore only by the grain matrix with low permeability. Those cements are syntaxially grown on the inner surface of the pore and fill the complete space. The shape of aggregate grains has some influence on the mechanical behaviour (Lanas and Alvarez 2003; Lanas et al. 2004). Grains with angular shapes and good packing build a higher strength of mortar. All samples contain sharp-edged grains, which interlock with the binder material. Additionally, numerous small splinters in micrometre size are embedded in the binder material around the aggregate grains. The binder material is densely packed with an almost homogene texture with a high micro-porosity. The pore size is less than $4 \mu \mathrm{m}$ and is visible in the thin sections on the blue colour made by the resin. Some areas in millimetre size are packed more compactly and can be explained by remains of larger carbonate grains after crushing. These lumps are incomplete slaked lime that is carbonated after the application of the material (Table 1).

The aggregate grains consist of medium- to coarsegrained volcanic material. The form is badly rounded and
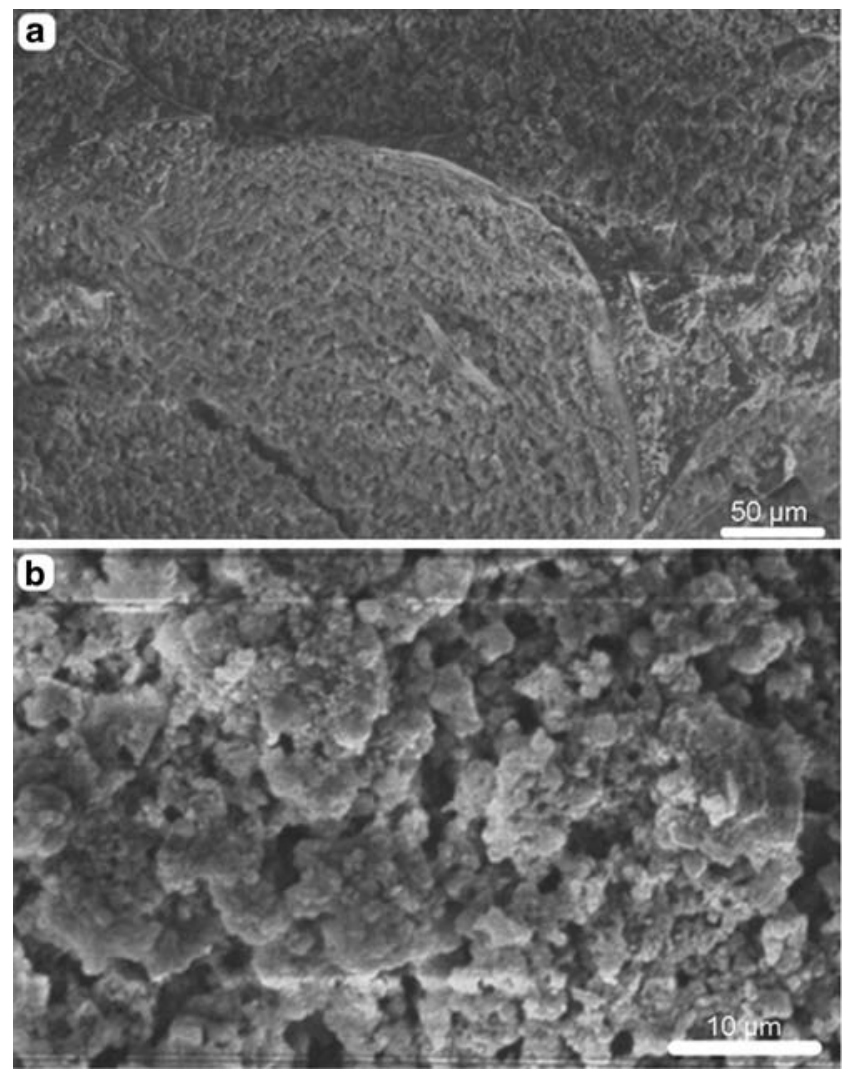

Fig. 5 SEM figure of ancient Qadhat samples. a Overview showing the dense binder with some small volcanic fragments. b The calcitic binder consisting of small, densely arranged crystals 
Fig. 6 Biplot of the water uptake versus the carbonate content. Field $A$ are samples nu1 and nu2, field $B$ are samples $\mathrm{n} 1$ and $\mathrm{n} 2$; they have similar carbonate content by very different water uptake behaviour. The other samples show a different carbonate content by similar water uptake

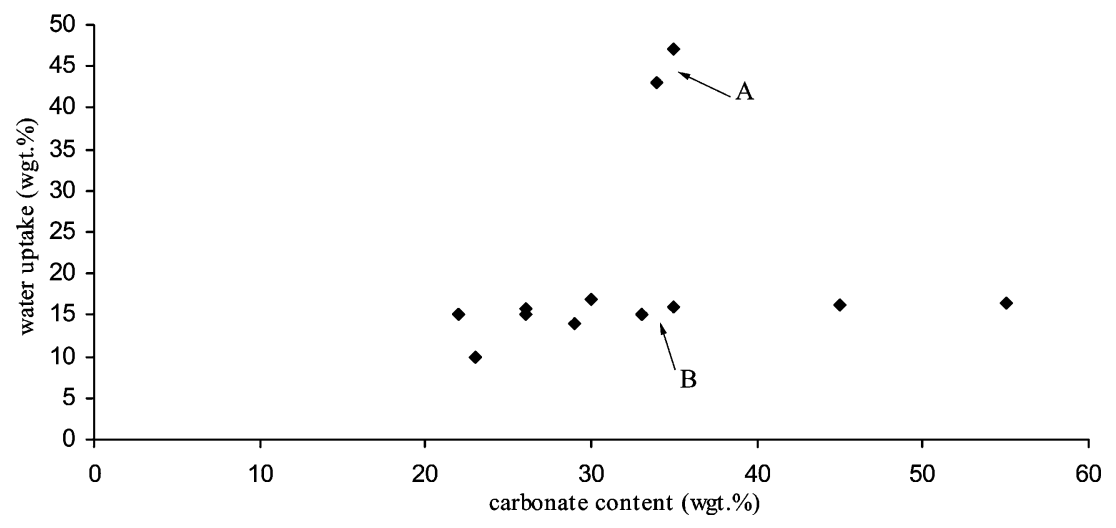

shaped. Grain size analyses of raw material and material after crushing the mortar (Fig. 3) show a reduction of larger grain size and an increase of the fine grain sized fraction depending on the time of working (Fig. 3).

The XRD results show that the composition is made of feldspars, carbonate and few clay minerals. The feldspars belong to the aggregates and the lime to the binder; the clay is contaminated by aerial dust. A high carbonate peak with almost no peaks of Portlandite $\mathrm{Ca}(\mathrm{OH})_{2}$ and low amounts of calcium silica in all samples indicate a fast carbonatisation of the binder (Figs. 4, 5).

The binder/aggregate relation $(\mathrm{B} / \mathrm{Ag})$ influences the compressive and flexural strength. As suitable $\mathrm{B} / \mathrm{Ag}$ ratio $1: 3$ is given by Moropoulou et al. (2002). Other works give similar strength by ratios of 1:4 and 1:5 (Lanas et al. 2004).

The carbonate content of the samples ranges between 22 and 35 wt.\%. Only two samples of Sabean ages have a content of 45 and 55 wt.\%. Those samples contain finegrained aggregates. According to the XRD analyses, which propose that carbonate is the main binder component, the ratios of the mortar samples ranging between 1:2 and 1:3.5. The samples with low carbonate content could be decarbonated by weathering. But in case of all samples, the visible weathering effects have been low and cracks due to shrinkage could not be observed. The B/Ag ratio does not agree with the given ratios for high stability.

Structurally bound water can be measured by the weight loss at temperatures between $200^{\circ} \mathrm{C}$ and $600^{\circ} \mathrm{C}$. The pozzolanic peaks in these regions are attributed to several calcium aluminium silicate hydrates $(\mathrm{CSH}, \mathrm{CAH}, \mathrm{Tb}$, $\mathrm{CACH}$ ), which bind water (Moropoulou et al. 2003). Weight loss by temperatures at $750^{\circ} \mathrm{C}$ corresponds to recarbonated lime including cementious material and in case of limestone clay also minerals (Moropoulou et al. 2003). Table 1 shows the weight loss of the samples, which have a very high and different weight loss at $750^{\circ} \mathrm{C}$. After Moropoulou et al. (2003), mortars with a weight loss of more than $8 \%$ can be classified as 'cementious'. But the high differences also suggest that factors other than structural-bound water are responsible for the weight loss. This can also be differentiated in the burning condition and in the hydrolysis as a content of organic material. The highest weight loss can be found in Sabaean samples. On the new samples, the uncrushed mortars show a significantly lower weight loss than the crushed ones (Fig. 6).

The results of the salt crystallisation test are different in all samples (Fig. 7). The untreated sample, consisting of binder and aggregates, as dense as the uncrushed mixture,

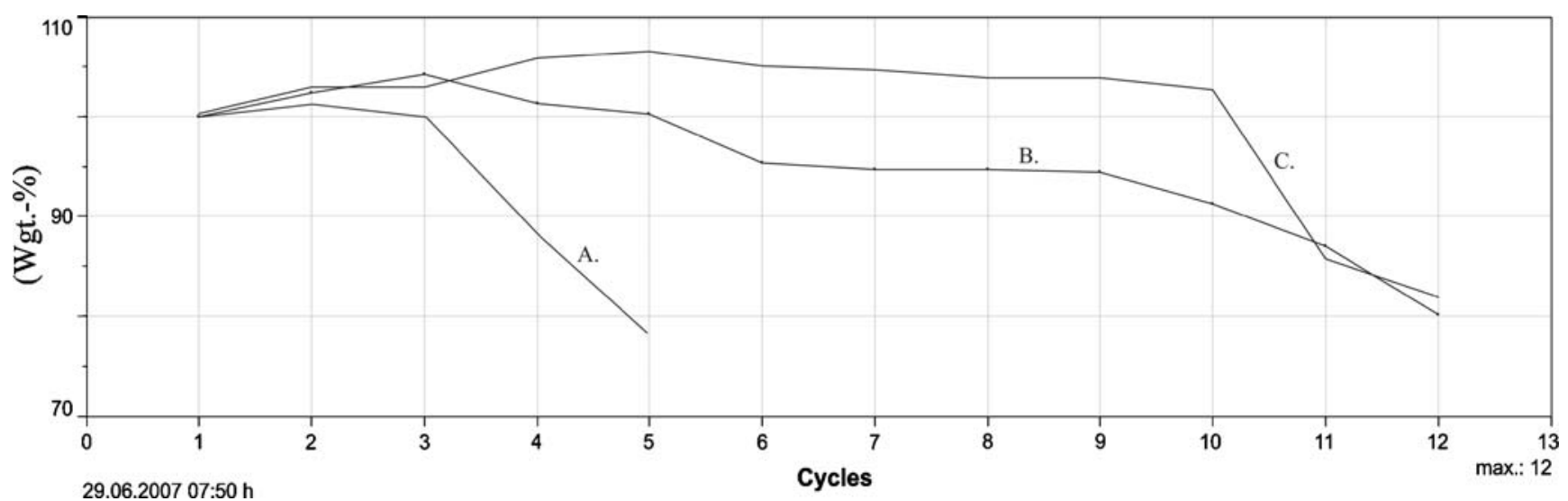

Fig. 7 The weight loss in percent during single cycles by the sodium sulphate-weathering test. Graph $A$ shows an unconsolidated sample, which was taken before crushing the material. The samples of Graph

$B$ are taken after $2 \mathrm{~h}$ and $C$ after $3 \mathrm{~h}$ crushing. The graphs show the dependence of stability on the production intensity 
shows a little increase in mass for 2 cycles and then a fast decay. Characteristic is the single aggregates loss without cracking. Sample B was crushed for $2 \mathrm{~h}$ and shows an increase in weight for 5 cycles before slow weight loss occurs up to the fifteenth cycle. Sample $\mathrm{C}$ was crushed for $3 \mathrm{~h}$ and shows a continuously high weight for 10 cycles before material decay. Both samples B and C show cracks which arose after the fifth (B) and the seventh (C) cycles. The sequence and form of decay show that the production process with crushing the material and compressing the binder is important for the stability. Fragmentation and compression increase the cohesive strength between the aggregates and the binder and lead to higher structural stability (Fig. 7).

The production process reduces the grain size of the aggregates by simultaneously compressing the binder material and stabilising them with small siliceous splinters. These effects provide stability and high elasticity. The impregnation with fat gives a further hydrophobation but should have no effect on the long-term resistance, which can be seen on the Bar'an temple and the dam in Marib.

Point of interest in a semi-arid area is the source of the burned lime which needs a high amount of energy resources. For the production of 1 ton of lime, 250 to $350 \mathrm{~kg}$ of wood will be needed to burn it (Bessey 1975; Meir et al. 2005). The most common trees in the Marib province were acacias (Lézine et al. 1998) which had a carolific effect of 4,400 to $4,680 \mathrm{kcal} / \mathrm{kg}$ which means about $250 \mathrm{~kg} / \mathrm{ton}$ of firewood. Because of the slow growth of the trees under semi-arid conditions, the production of firewood must have been enormous to provide lime as the sealant material for irrigation systems. The consequences are discussed by Garfinkel (1987) and Rollefson (1990). For the Marib Oasis, more detailed analyses are necessary. The total amount of burned lime and the possible wood sources are unknown.

\section{Conclusion}

(1) The high quality and weathering resistance of Qadhat depends on the choice of material and the production process. All components are suitable in respect of the purpose of the mortar and are selected from a wide range of possible materials which exist in the area. (2) The production process of crushing the mortar to reduce the grain size and to increase the compaction provides the high quality of this mortar. Furthermore, the role of pozzolanic reactions is questionable for the stability of the mortars. By crushing und reducing the grain size of the aggregates, an increase in the surface of the volcanic glass is produced. But, the XRD diagrams only show small peaks of calcium silicates which are little higher than the background snow.
In thin sections, no weathered margin could be found which shows a possible reaction between the volcanic glass and the carbonate. Both the XRD diagrams and the thin sections seem to support the assumption of producing the high stability by the compaction of the material. The weight loss by heating is very different and could be affected by other reactions.

The similarity of the sample composition and the material suggests a long, continuous tradition in producing this special mortar by similar methods. Particularly, the texture of the samples with coarse-grained fragile volcanic clasts, areas with low density and small volcanic splinters in the binder suggest similar production processes in history. The composition of the material and the material selection, as well as the intensive production process, confirm a high technological standard in mortar production.

The provenance of the ancient mortar components can be determined by the mineralogy of the aggregates. The origin of the lime cannot be proven; further analyses (trace elements) are necessary. The volcanic material originates in the surrounding area of Marib and Sirwah; the origin of the lime, however, could be the Jurassic limestone of the Marib area or the limestones of the Hardramwat region (Eastern Yemen) or some other region. Only the high amount of ancient material suggests an origin in the surrounding area.

Acknowledgements Thanks to Prof. Roman Koch, Dr. Ueli Brunner and Dr. Sarah Japp for their help and contribution to this work.

\section{References}

Arnold A, Zehnder K (1989) Salt weathering on monuments. In: Zezza F (ed) Proceedings of the First International Congress on the Conservation of Monuments in the Mediterranean Basin, Bari, 7-10 June. Grafo, Brescia, Italy, pp 31-58

Bessac JC (1998) Techniques de construction, de gravure et d'ornamentation en pierre da la Jawf. Foullies de Shabwa III: $174-230$

Bessey G E (1975) Production and use of lime in developing countries. In: H.M.S.O. (ed) 1980, Building in Hot Climates-A Selection of Overseas Building Notes, Prepared by the Overseas Division of the Building Research Establishment, Her Majesty's Stationary Office 161: 29-47

Brunner U (1989) Die Bausteine der Sabäer. Münchner Beiträge zur Völkerkunde 2:27-42

Brunner U (1998) Der große Damm von Marib - ein technisches Weltwunder der Antike. In: W. Seipel (ed) Jemen Kunst und Archäologie im Land der Königin von Saba', Wien, 63 - 67

Brunner U, Haffner H (1986) The successful floodwater farming system of the Sabaeans, Yemen Arab Republic. Applied Geography 6:77-89

Garfinkel Y (1987) Burnt lime products and social implications in the pre-pottery Neolithic B villages of the Near East. Paléorient 13 (1):69-76

Gerlach I (2003) Die archäologisch-bauhistorischen Untersuchungen in der sabäischen Stadtanlage und Oase von Sirwah. Neue 
Forschungen des Deutschen Archäologischen Institutes 2002. Hefte zur Kulturgeschichte des Jemen 1:96-105

Klessing JM (1997) Das traditionelle Flachdach im Jemen am Beispiel der Sanierung der ,Samsarat al-Mansura' in Sana'a. Detail 5:698-702

Kruck W, Schäffer U, Thiele J (1996) Explanatory notes on the geological map of the Republic of Yemen-western part (former Yemen Arab Republic). Geol. Jb. B 87:105

Lanas J, Alvarez JI (2003) Masonry repair lime-based mortars: Factors affecting the mechanical behaviour. Cem Concr Res 33:18671876

Lanas J, Pérez Bernal JL, Bello MA, Alvarez Galindo JI (2004) Mechanical properties of natural hydraulic lime-based mortars. Cem Concr Res 34:2191-2201

Lézine AM, Saliége JF, Robert C, Wertz F, Inizan ML (1998) Holocene lakes from the Ramlat as Sab'atayn (Yemen) illustrate the impact of monsoon activity in southern Arabia. Quat Res 50:220-259

Meir IA, Freidin C, Gilead I (2005) Analyses of Byzantine mortars from the Negev Desert, Israel, and subsequent environmental and economic implications. J Archaeol Sci 32:767-773

Moropoulou A, Cakmak AS, Biscontin G, Bakolas A, Zendri E (2002) Advanced Byzantine cement based composites resisting earth- quake stresses: the crushed brick/lime mortars of Justinian's Hagia Sophia. Constr Build Mater 16:543-552

Moropoulou A, Polikreti K, Bakolas A, Michailidis P (2003) Correlation of physicochemical and mechanical properties of historical mortars and classification by multivariate statistics. Cem Concr Res 33:891-898

Price CA (1975) Testing porous building stone. AIA J 2(33):337-339 Rollefson GO (1990) The uses of plaster at Neolithic, Ain Ghazal Jordan. Archeomaterials 4:33-54

Scherer GW, Flatt RJ, Wheeler G (2001) Materials science research for the conservation of sculpture and monuments. MRS Bull 26(1):44-50

Vogt B (2003a) Die Konservierung und touristische Erschließung des Almaqah-Tempels von Bar'an in der Oase von Marib, 19942000. Neue Forschungen des Deutschen Archäologischen Institutes 2002. Hefte zur Kulturgeschichte des Jemen 1:70-77

Vogt B (2003b) Der Grosse Damm von Marib-Neue Forschungen des Deutschen Archäologischen Institutes 2002. Hefte zur Kulturgeschichte des Jemen 1:78-85

Vogt B (2004) Grundzüge der antiken südarabischen Bewässerungslandwirtschaft. Beitr Allg Vgl Archäol 24:67-104

Weiss C, Koch R, Gerlach I (2007) Jurakalke im Almaqah-Tempel von Sirwah, Nordjemen - Verwendung, Verwitterung und Herkunft. Z dt Ges Geowiss 158/3:571-592 